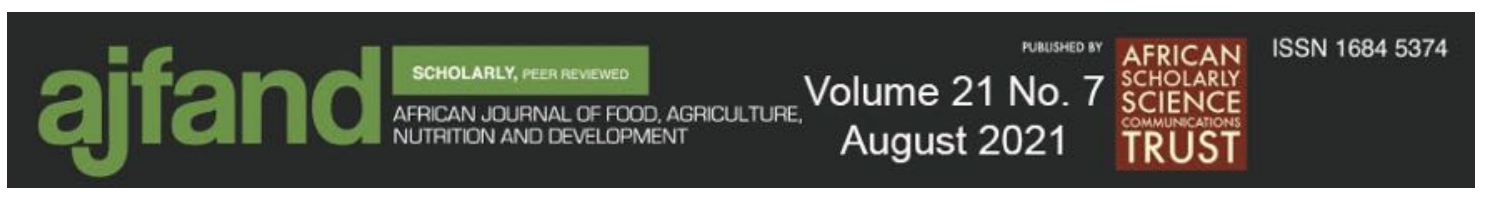

Afr. J. Food Agric. Nutr. Dev. 2021; 21(7): 18368-18390 $\quad$ https://doi.org/10.18697/ajfand.102.20140

\title{
EVALUATION OF A SEED STORAGE FACILITY IN RELATION TO PRESERVING SEED MOISTURE, VIGOUR AND GERMINATION
}

Mdlalose $S^{1,2}$, Workneh $T^{1}$, Sibanda $S^{2 *}$ and M Laing ${ }^{1}$

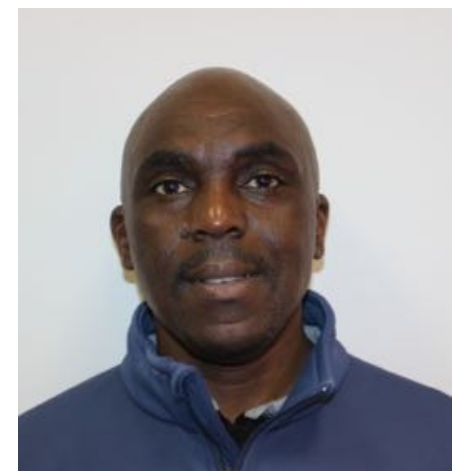

Sipho Sibanda

*Corresponding author email: sibandas@arc.agric.za

${ }^{1}$ Department of Bioresources Engineering and Environmental Hydrology, University of KwaZulu-Natal, Private Bag X01, Pietermaritzburg, South Africa

${ }^{2}$ Institute of Agricultural Engineering, Agricultural Research Council, Private Bag X519, Pretoria, South Africa 


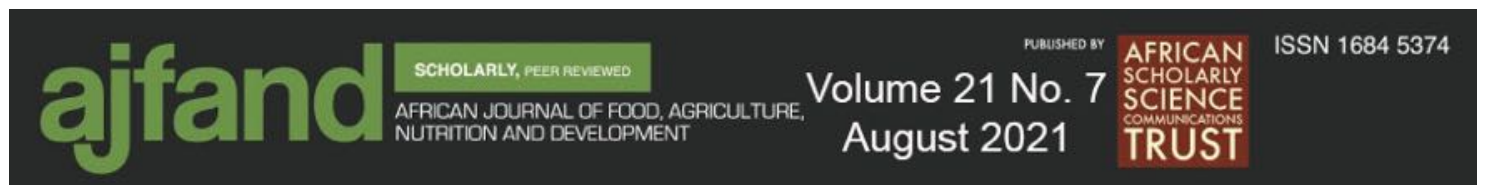

\begin{abstract}
The performance of a solar energy-assisted seed storage room was evaluated through an ordinary $22-\mathrm{m}^{3}$ room that was retrofitted with a solar collector, inlets and chimney. The structure was made of a solar collector to heat the ambient air before entering the chimney. The chimney circulated the air inside the structure and inlets. To compare the performance of the modified storage room, a room with a similar capacity and without the retrofitted components (control storage room) was used. Twelve $8 \mathrm{~kg}$ bags of maize were stored in each storage room for a period of three months. Samples were taken every two weeks to determine germination rate, moisture content and seed vigour. The temperature and relative humidity $(\mathrm{RH})$ was measured during storage. The $\mathrm{RH}$ in the control storage was significantly higher $(\mathrm{P} \leq 0.05)(60.6 \pm 5.87 \%)$ than in the modified storage (40.1 $\pm 3.21 \%)$ during the day. However, at night, the RH in the control storage room was significantly lower $(\mathrm{P} \leq 0.05)(58.5 \pm 7.32 \%)$ than in the modified storage $(63.7 \pm 6.28 \%)$. The $\mathrm{RH}$ in the modified storage room increased from $40.1 \%$ during the day to $63.7 \%$ at night. The RH in the control storage room decreased slightly from $60.6 \%$ to $58.5 \%$ during the day and night. The seed moisture content in the modified storage facility was significantly lower $(\mathrm{P} \leq 0.05)(12.6 \pm 0.21 \%)$ than in the control storage room $(13.3 \pm 0.52 \%)$. The moisture content in the modified storage room decreased from $12.6 \%$ to $12.4 \%$, whereas in the control room, moisture content increased from $12.6 \%$ to $13.8 \%$ in three months. The seed germination rate obtained after three months of storage in the modified storage room was significantly higher $(\mathrm{P} \leq 0.05)(98.5 \pm 0.85 \%)$ than in the control storage room $(96.8 \pm 1.49 \%)$. The seed vigour obtained in the modified storage room was significantly higher $(93.6 \pm 0.35 \%)$ than in the control room $(91.7 \pm 2.08 \%)(\mathrm{P} \leq 0.05)$. Seed stored in the control storage lost vigour at a faster rate, compared to the seeds stored in the modified storage room. Therefore, the modified naturally-ventilated seed storage room maintained seed quality better than the control storage room.
\end{abstract}

Key words: relative humidity, temperature, natural ventilated, solar energy assisted 


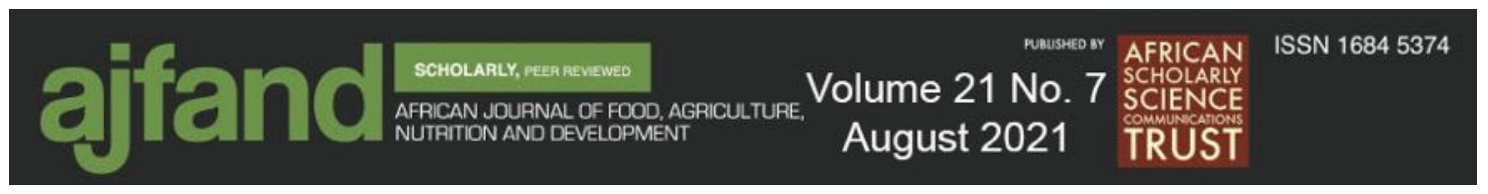

\section{INTRODUCTION}

Seed moisture, vigour and germination are some of the most important parameters for assessing seed quality, especially, for plant breeders. To preserve the quality of seeds, proper storage facilities are required. Factors affecting the quality of stored seeds are micro-organisms, temperature, relative humidity $(\mathrm{RH})$, moisture content, carbon dioxide, insects, mites, rodents, the characteristics of the stored seed, the geographical location of the structure, the structure of the seed facility and oxygen level $[1,2,4,5]$. The current available traditional structures in most sub-Saharan African countries are made of wheat straw, which are permissible to rodents, pests, and insects. Other traditional structures are underground storage structures, bamboo/reed structures, masonry structures and earthen storage structures that present different challenges [6] which affect the quality of stored seeds. Govender et al. [7] studied the germination and seed vigour of maize seed stored, using traditional methods for a period of one year. In their study, seeds were stored in plastic bags in a general storage room, where there was no air conditioning, temperature fluctuated between 35 and $37^{\circ} \mathrm{C}$ and the samples were exposed to insect damage. In this type of storage room, maize germination dropped from $88.7 \%$ to $0.0 \%$ and there was a loss of vigour. In a study by Weinberg et al. [8], maize seeds stored in hermetic bags, with moisture content of $20 \%-22 \%$ and under the temperature of $30^{\circ} \mathrm{C}$, had a low vigour and germination, compared to the maize seeds stored at a moisture content of $14 \%$ for the same duration of 75 days. This study showed the negative effects of high moisture during storage.

When the levels of RH and temperature are simultaneously high, there is a high rate of physiological activity in seeds, resulting in accelerated deterioration $[9,10]$. On the other hand, a low RH and low temperature decrease infestation by microorganism $[11,12]$. Moren-Martinez et al. [13] stored maize seed at a temperature of $25^{\circ} \mathrm{C}$, a $\mathrm{RH}$ of $75 \%$ and $85 \%$ and a $13.8 \%$ moisture content for 120 days. Seeds stored at a RH of $85 \%$ lost germination ability completely after 30 days, while those stored at a $\mathrm{RH}$ of $75 \%$ lost germination ability after 120 days. In another study, Joao Abba et al. [14] subjected maize seed to three storage conditions of $\left(20^{\circ} \mathrm{C}+45-50 \% \mathrm{RH}, 25^{\circ} \mathrm{C}+65-70 \% \mathrm{RH}\right.$, and $\left.30^{\circ} \mathrm{C}+90-95 \% \mathrm{RH}\right)$ for a duration of 420 days. At $30^{\circ} \mathrm{C}+90-95 \% \mathrm{RH}$, the seeds lost viability and vigour completely. Furthermore, the equilibrium moisture content increased from $10.5 \%$ to $17 \%$ and the $20^{\circ} \mathrm{C}+45-50 \% \mathrm{RH}$ conditions were found to be favourable for storing maize seeds for the period of one year. The conditions $\left(25^{\circ} \mathrm{C}+\right.$ $65-70 \% \mathrm{RH}$ ) was recommended for the storage of seeds for no longer than 3-4 months. This shows that an elevated temperature and RH reduces the quality of stored seed at a faster rate. Eighteen crop species were stored for 23 years by Nagel and Börner [15] at a temperature of $20.3 \pm 2.3^{\circ} \mathrm{C}$ and a $\mathrm{RH}$ of $50.3 \pm 6.3 \%$. It was found that maize sustained viability for 19 years. Maize seeds were stored under two storage conditions of temperature of $25^{\circ} \mathrm{C}$ and a $\mathrm{RH}$ of $75 \%$ and at a temperature of $12^{\circ} \mathrm{C}$ and a $\mathrm{RH}$ of $60 \%$, and the seed vigour was monitored during storage [16]. Seed stored at $12^{\circ} \mathrm{C}$ and at a $60 \% \mathrm{RH}$ had small decline in seed vigour, compared to the seed store at $25^{\circ} \mathrm{C}$ and a $75 \% \mathrm{RH}$. At a higher temperature and $\mathrm{RH}$, seeds lose quality at a greater rate, while the inverse is true. 


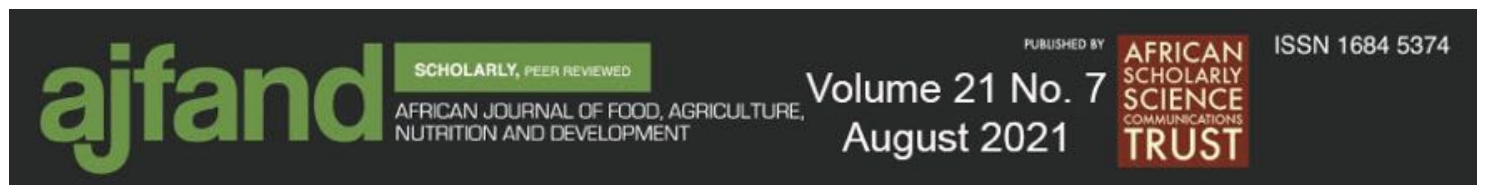

It is, thus, necessary to use a seed storage facility that reduces the RH to reduce the moisture content of stored seeds. It is recommended that after harvesting, seeds should be dried to a safe moisture content for storage [6]. Achieving a safe moisture content during storage improves the storability of seed and lowers the risk of spoilage [17]. A safe moisture content during storage is $<14-15 \%$ wet basis [18]. However, seeds are harvested at a moisture content of $20-30 \%$ and should therefore, be dried to less than $13-13.3 \%$ prior to storage $[10,19,20]$. This ensures that the storage facility is kept within a safe moisture content limit.

Therefore, the objective of this study was to test the developed naturally-ventilated seed storage facility for preserving the quality of the stored seeds, namely, germination, seed vigour and moisture content.

\section{MATERIALS AND METHODS}

\section{Experimental site and climatic data}

The experiment was carried out at the University of KwaZulu-Natal Ukulinga Research Farm, in Pietermaritzburg, South Africa $\left(30^{\circ} 24^{\prime} \mathrm{S}, 2^{\circ} 24^{\prime} \mathrm{E}\right)$. Ukulinga Research site is located at an altitude of $721 \mathrm{~m}$ and experiences a mean annual temperature of $18.4^{\circ} \mathrm{C}$, with summers ranging from warm to hot and mild winters [21]. The average wind speed in Pietermaritzburg has been reported to be $0.8 \mathrm{~m} \cdot \mathrm{s}^{-1}$ for the past two decades, and in recent years, the maximum wind speed reached was $9.7 \mathrm{~m} . \mathrm{s}^{-1}$. East-southeast is the prevailing wind direction in PMB [22].

\section{Description of the solar energy-assisted seed storage facility}

The solar energy assisted seed storage facility had a volume of $22 \mathrm{~m}^{3}$ and consisted of a roof integrated solar collector for heating the air before it enters the storage room. The structure had a solar collector (polycarbonate sheets) with an area of $11 \mathrm{~m}^{2}$ covering the entire roof, an inlet galvanised steel pipes to the room, with a total area of $0.066 \mathrm{~m}^{2}$, and an outlet chimney, with an area of $0.071 \mathrm{~m}^{2}$ (diameter) and a height of $4.8 \mathrm{~m}$ (Figure 1). The solar chimney used was made of Galvanized steel and was painted black. The solar collector had clear corrugated polycarbonate sheets with a standard thickness of $1 \mathrm{~mm}$, a width of $760 \mathrm{~mm}$ and a length of $3.5 \mathrm{~m}$. The polycarbonate sheets were supported by a frame made of mild steel bars, with a cross-sectional area of $3 \mathrm{~mm}$ by $50 \mathrm{~mm}$ ). The corrugated iron sheets underneath the polycarbonate sheets were painted black for enhancing the absorption of radiation and a space of $10 \mathrm{~cm}$ was left between them, as an air channel. 

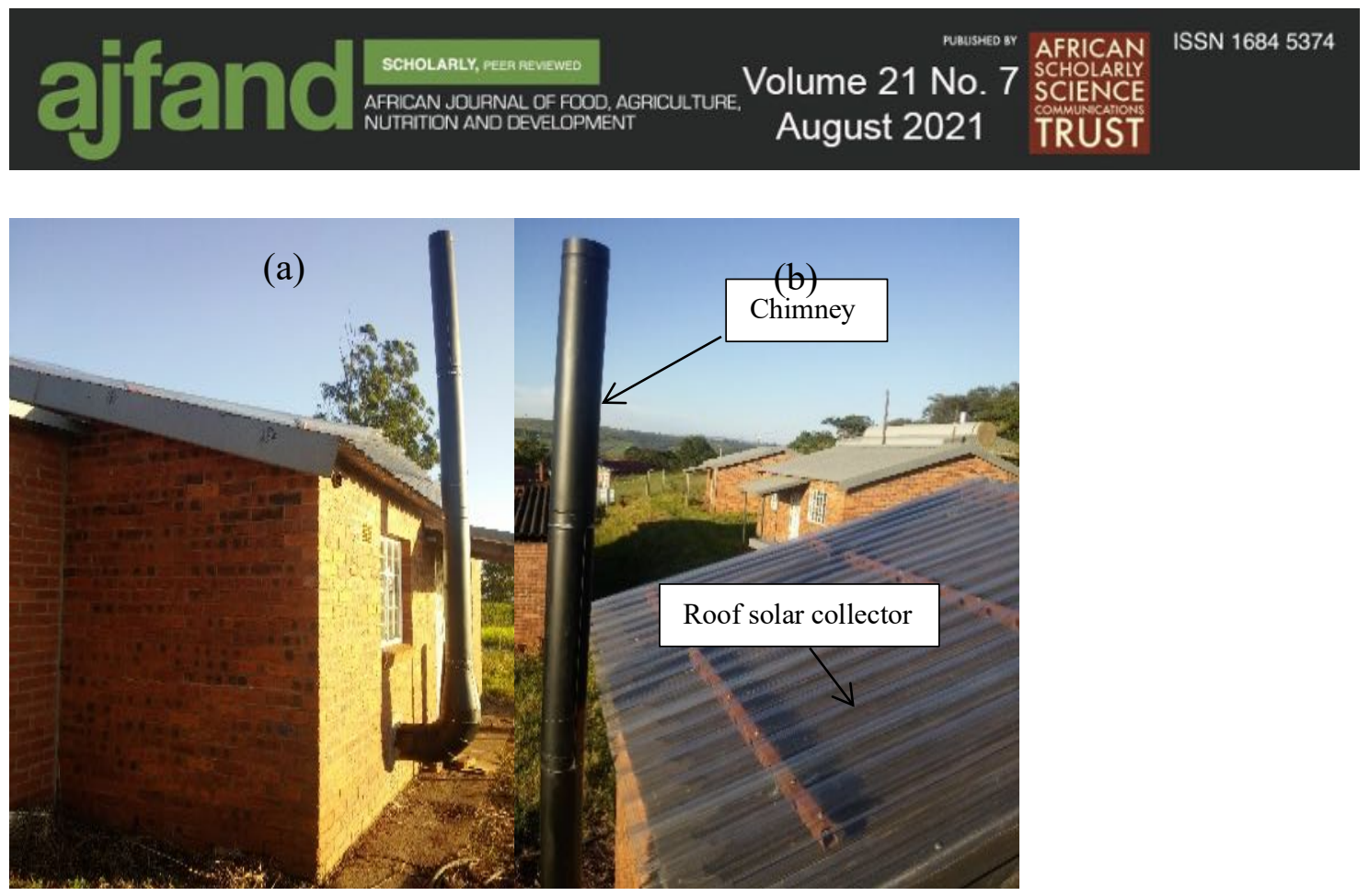

Figure 1: Picture (a) modified storage and picture

(b) solar collector system on the roof

\section{Experimental Procedure}

Two storage rooms, namely, a control and a modified storage, were evaluated. A yellow maize (CAP 9-522 variety) was used in this experiment. Three bags of seeds of a weight of $8 \mathrm{~kg}$ were loaded in each of the storage facilities. The seed bags were sampled in each storage room for germination, seed vigour and moisture content determination and Figure 2 shows the experimental design.

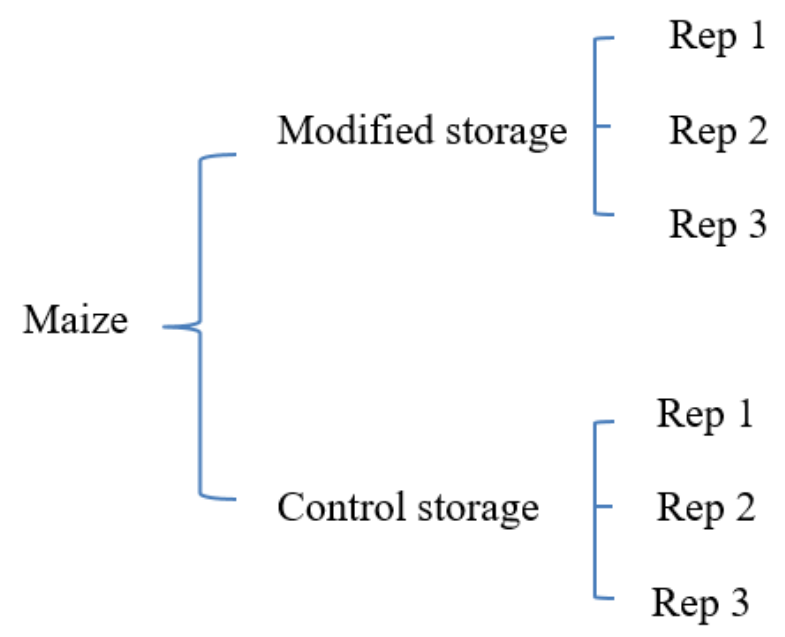

\section{Figure 2: Experimental design}

\section{Data collection}

\section{Moisture content determination}

The moisture content of the seed grains was determined according to the official method of the Association of Official Analytical Chemistry Horwitz et al. [23] as follows:

(a) grain was ground to pass a $1 \mathrm{~mm}$ sieve 


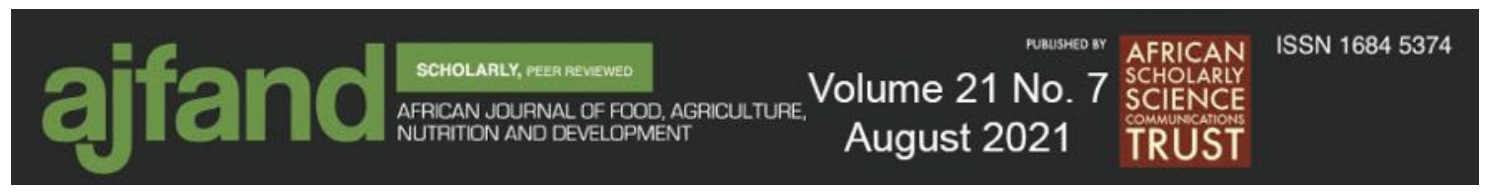

(b) $2 \mathrm{~g}$ of ground grain was weighed

(c) $2 \mathrm{~g}$ was dried for one hour at $130^{\circ} \mathrm{C}$

(d) moisture content was expressed on wet basis using the following formula by Horwitz et al. [23]

$M_{w b}=\frac{M_{w}}{M_{w}+M_{d}}$

Where

$\mathrm{M}_{\mathrm{wb}}=$ moisture content in the wet-basis [\%],

$\mathrm{M}_{\mathrm{w}}=$ is the mass of water [kg], and

$\mathrm{M}_{\mathrm{d}}=$ is the mass of dry matter of the product [kg].

\section{Standard germination}

Fifty seeds were germinated at a temperature of $25^{\circ} \mathrm{C}$ under no light conditions in the germinator according to the procedures of Janmohammadi et al. [24] and iGrow Corn [25]. Seeds were checked for germination every day for seven days, from the third day. The seed was counted as germinated when the radicle had protruded to a length of 3 $\mathrm{mm}$. Percentage germination was calculated, using equation 2 by Soltani et al. [26]:

$\%$ Germination $=\frac{\text { Number of seedling emerged }}{\text { Number of seeds sown }} \times 100$

\section{Seed vigour by Accelerated Ageing Test}

The Accelerated Ageing Test was carried out to test whether the seed had the strength to germinate with success under harsh conditions. A bag of seeds $(8 \mathrm{~kg})$ were exposed to a $\mathrm{RH}$ of $96 \%$ and a temperature of $45^{\circ} \mathrm{C}$ for 72 hours in the AA machine [27]. After accelerated ageing, the seeds were subjected to standard germination test. Temperature and $\mathrm{RH}$ were recorded using the HOBO U23 Pro v2 Temperature/Relative Humidity Data Logger, with $0.2^{\circ} \mathrm{C}$ and $2.5 \%$ accuracy at intervals of 30 minutes every day, from 20 March 2017 to 19 June 2017. 




Temperature and relative humidity measurements
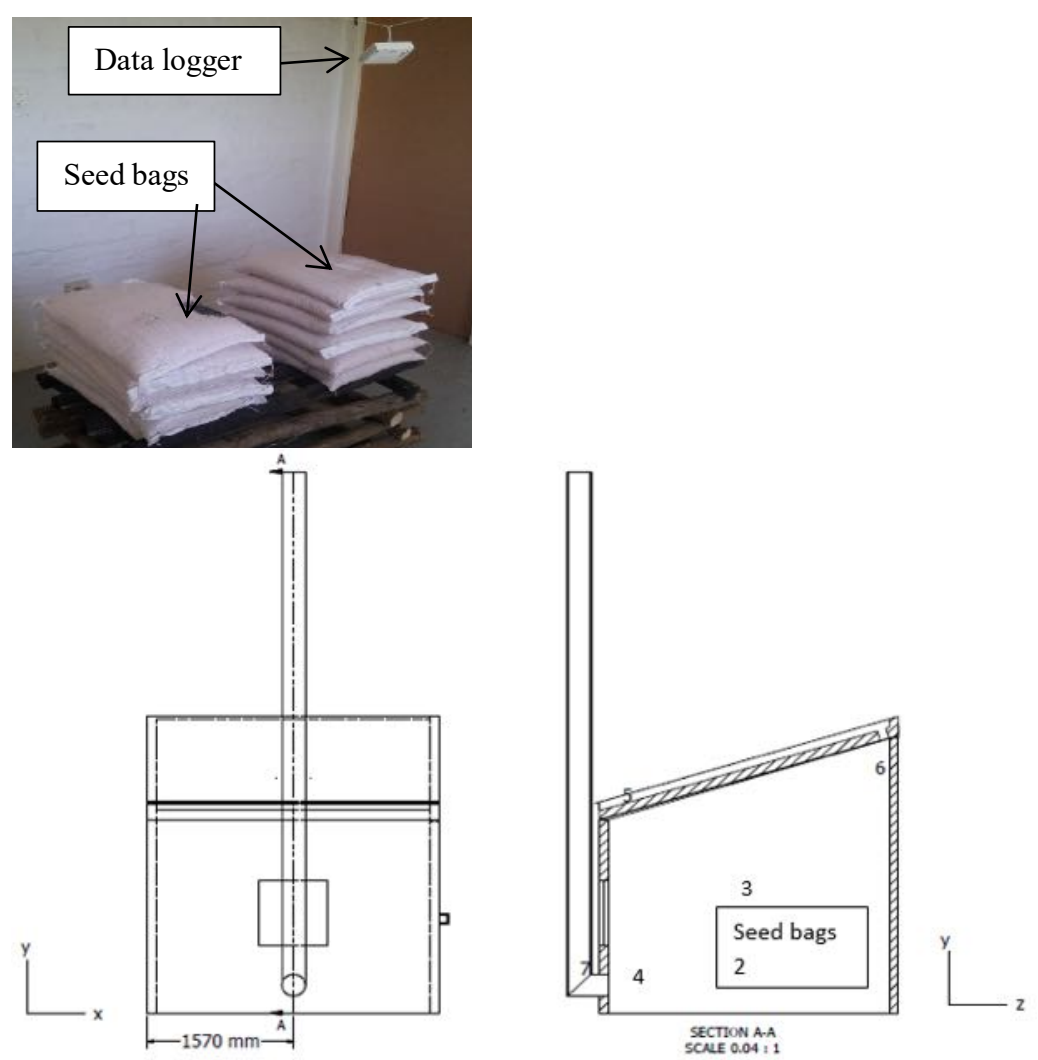

Figure 3: (a) Seed bags in the storage (b) Position 7 (chimney duct) measures the airflow velocity, whereas, points-2 (inside seed bags), 3 (room centre), 4 (outlet) and 6 (air inlet) measure temperature/relative humidity respectively at $x=1.57 \mathrm{~m}$

The temperature and air RH were recorded inside the seed bags (2) and at the center of the storage room (3) for both storage types (see Figure 3). The quality parameters of maize seed (germination, moisture content and vigour) were measured at two-week intervals, for the entire period of storage.

\section{Data Analysis}

An analysis of variance for temperature, $\mathrm{RH}$, moisture content, standard germination and vigour was carried out with Genestat18 and Excel 2016, using a 5\% level of significance.

\section{RESULTS AND DISCUSSION}

Relative humidity and temperature at the centre of storage facilities during the day

Table 1 shows the changes in air temperature inside both storage facilities. There was a rapid variation of the air temperature in both storage rooms throughout the storage period. This was caused by the changes in external environmental conditions. There was a significant difference $(\mathrm{P} \leq 0.05)$ between the air temperature in modified storage 


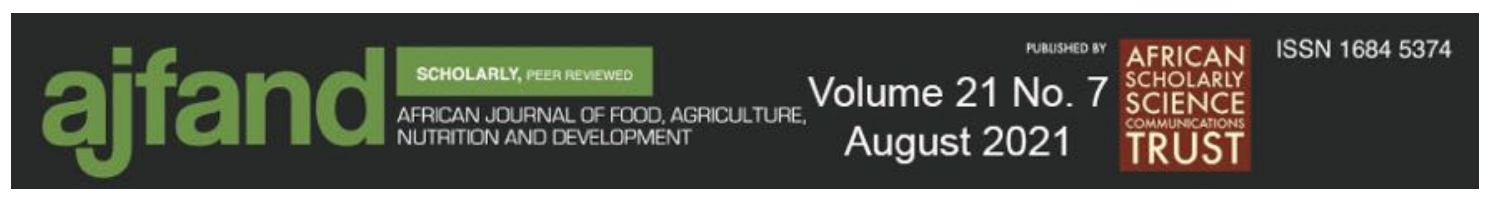

and the control rooms during the day where the mean air temperature was $(24.4 \pm$ $\left.3.89^{\circ} \mathrm{C}\right)$ and $\left(19.5 \pm 2.99^{\circ} \mathrm{C}\right)$, respectively. The average temperature was $24.4^{\circ} \mathrm{C}$ over the three months of storage from March through to June, which are cold months of the year in this region, and this is the reason why the average temperature in the modified storage room was low.

The average temperatures in the modified storage room were higher during the day, since the solar collector heated the air that entered. Between March and April, the temperatures were as high as $35^{\circ} \mathrm{C}$ in the storage room, while between May and June, temperatures dropped to below $27^{\circ} \mathrm{C}$ inside the modified storage room as winter approaches. Temperatures in the control storage room were always below the modified storage (Figure 4), which implies that the modified storage was operating optimal. Temperature and $\mathrm{RH}$ are important and interact during storage [4]. In the current study, the modified storage achieved a $\mathrm{RH}$ of $40.1 \pm 3.21 \%$ and a temperature of $24.4^{\circ} \mathrm{C}$ which are close to the recommendations of Joao Abba et al. [14] of $45-50 \% \mathrm{RH}$ and $20^{\circ} \mathrm{C}$ for the seeds to maintain quality traits (viability and vigour) for one year. Therefore, it is possible to store seeds in the modified storage room, under day conditions, for one year.

During the day, there was a significant difference $(\mathrm{P} \leq 0.05)$ between the $\mathrm{RH}$ in the modified room $(40.1 \pm 3.21 \%)$ and the control storage room $(60.6 \pm 5.87 \%)$ (Table 1$)$ over the entire storage period (Figure 4). From March through June, the RH declined as these are the cold months of the year. The storage conditions of $74 \% \mathrm{RH}$ combined with a 12\% moisture content was good for enhancing shelf life for seeds as reported by Brownfield and Seeds [28]. 

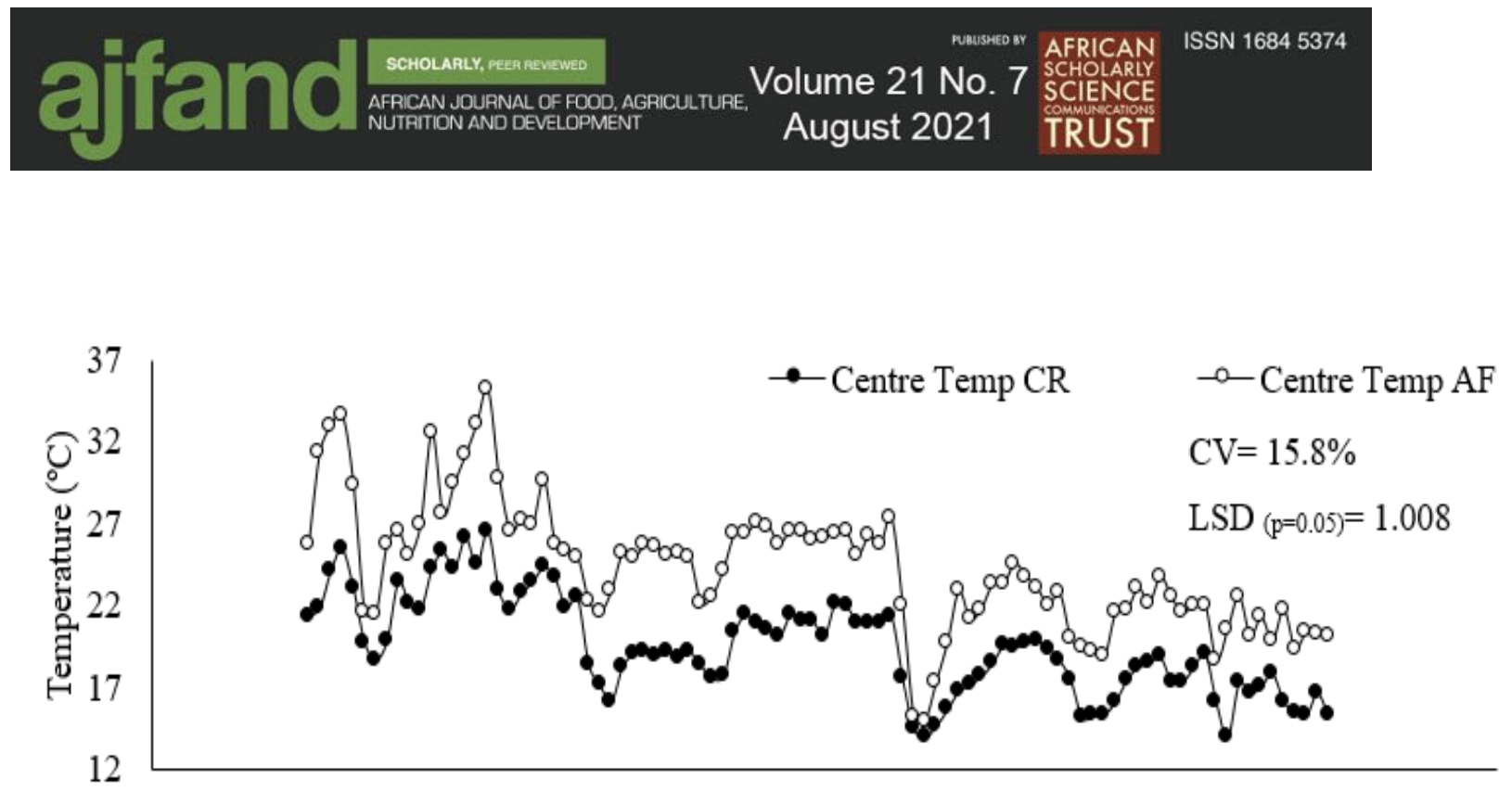

06 March 201726 March 2017 15 April $2017 \quad 05$ May $2017 \quad 25$ May $2017 \quad 14$ June $2017 \quad$ 04 July 2017

Date

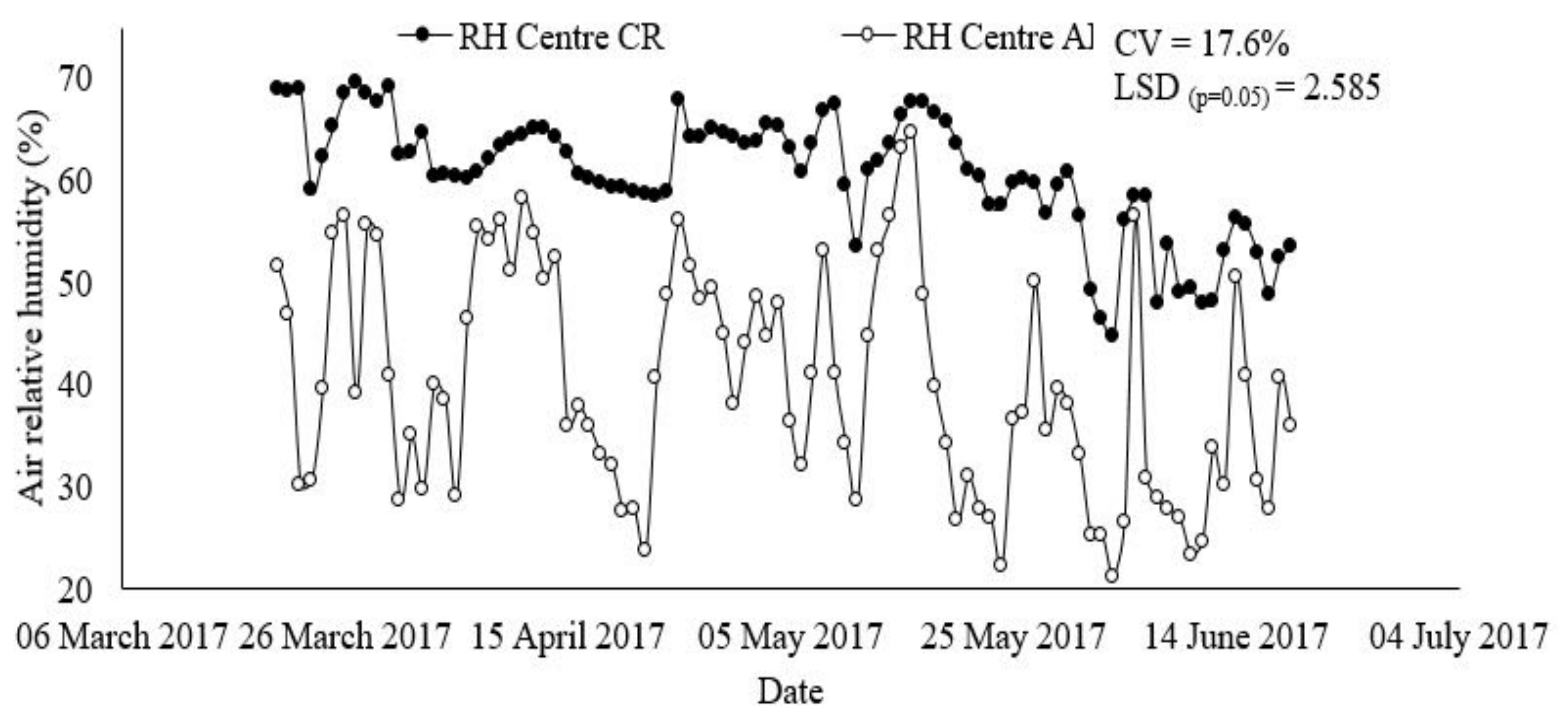

Figure 4: Centre temperatures and relative humidity for control room (CR) and modified room (AF) during the day

The results of this study showed that the levels of $\mathrm{RH}$ were below $74 \%$ in both the modified and control storage rooms and inside the seed bags. According to Lee et al. [29], maize stored at a temperature of $25^{\circ} \mathrm{C}$ and $\mathrm{RH}$ of $80 \%$ can be kept for five months in the storage room. Therefore, the maize stored in the modified and control storage rooms in this study could conserve its qualities for five months, since the conditions of $24.4^{\circ} \mathrm{C}+40.1 \% \mathrm{RH}, 19.5^{\circ} \mathrm{C}+60.6 \% \mathrm{RH}$, respectively are in agreement with the results obtained by Lee et al. [29]. However, for the prolonged storage of maize seeds (one year), the conditions obtained in control room might not be conducive according to Joao Abba et al. [14] who concluded that for seed to be stored for a year, storage facilities conditions should be $20^{\circ} \mathrm{C}$ and at a $\mathrm{RH}$ of $45-50 \%$. 


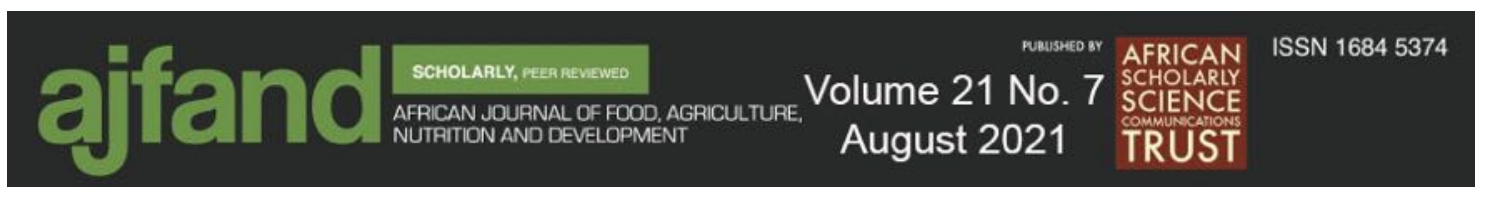

Air relative humidity and temperature in the seed bags during the day

Temperature inside the seed bags in the modified storage room was significantly higher $(\mathrm{P} \leq 0.05)$ than the temperature inside the seed bags in the control storage room.

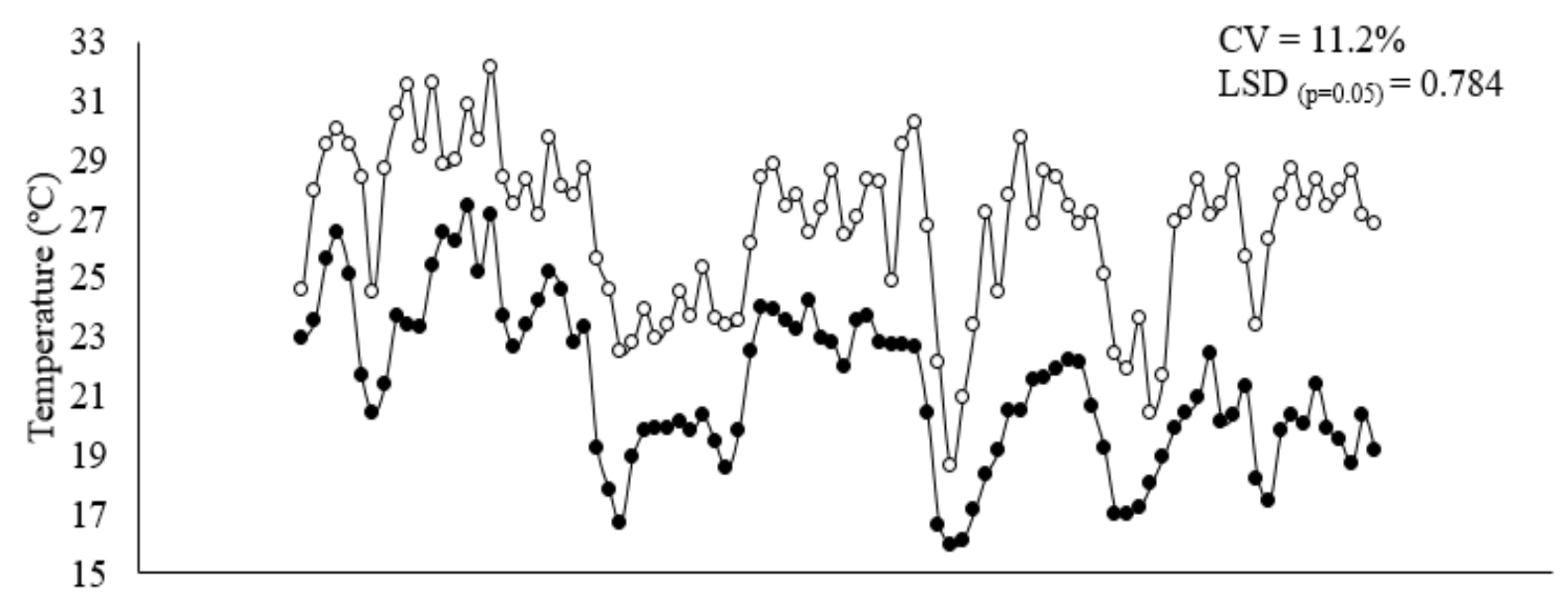

06 March 201726 March 2017 15 April 2017 05 May 2017 25 May 2017 14 June 2017 04 July 2017

Date

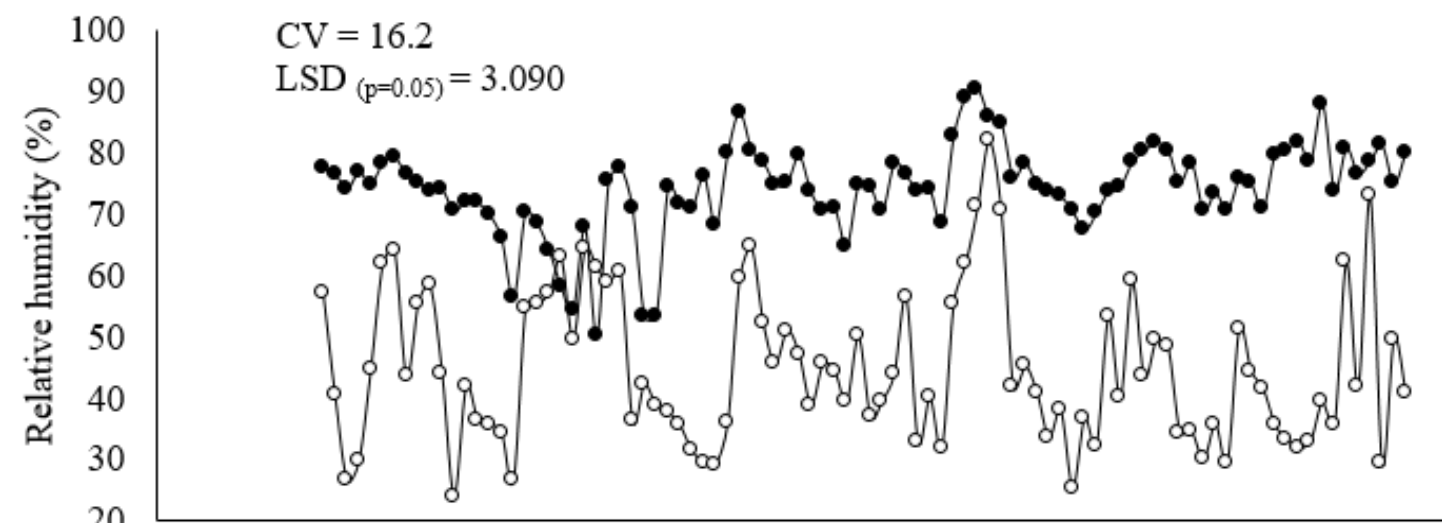

06 March 201726 March $2017 \quad 15$ April $2017 \quad$ 05 May $2017 \quad 25$ May 2017 14 June $2017 \quad$ 04 July 2017

Date

\section{$\rightarrow$ RH bag $\mathrm{CR} \quad-$ - $\mathrm{RH}$ bag $\mathrm{AF}$}

Figure 5: Seed bag temperature and relative humidity for control room $(C R)$ and modified room (AF) during the day

This is observed in Figure 5 where the average temperature in the modified room was $26.7 \pm 2.7^{\circ} \mathrm{C}$ while that in the control storage room was $21.4^{\circ} \mathrm{C}$. At elevated temperatures and $\mathrm{RH}$, seeds tend to lose viability and vigour quicker, according to Šimić et al. [16] and Matthes et al. [30], and seeds stored at $12^{\circ} \mathrm{C} / 60 \%$ aged slower than seeds stored at $25^{\circ} \mathrm{C} / 75 \%$. The modified storage had an average temperature of $26.7^{\circ} \mathrm{C}$, which corresponds to an average $\mathrm{RH}$ of $40.1 \%$. The effect of an elevated temperature was however masked by a low RH. The storage temperature can be varied widely if the seeds are dried to a safe storage moisture and that the RH and does not 


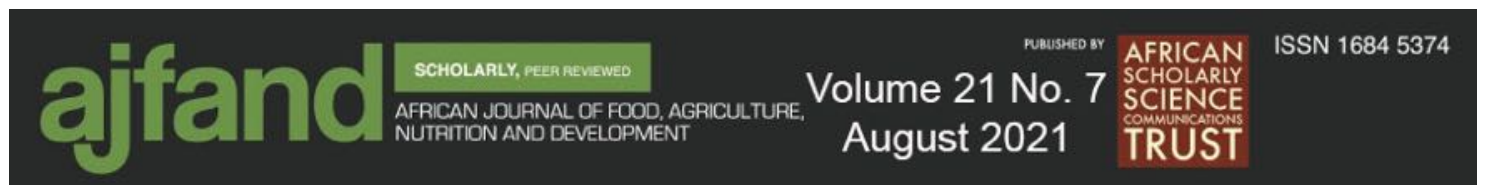

shift towards the equilibrium moisture during storage as reported by Jelle [31]. The effect of temperature during storage is exaggerated when seeds are stored above a safe moisture content of 14\% [32]. For instance, Suleiman [3] reported that for seeds kept at a $16 \%$ moisture content and at a temperature of $32^{\circ} \mathrm{C}$ and $35^{\circ} \mathrm{C}$, the seeds stored at the later temperature deteriorated quicker. At higher temperatures, seed quality losses are high. Similar results were obtained by Wang [33], where moisture content used was higher $(35 \%)$ and at temperatures of $20^{\circ} \mathrm{C}, 8^{\circ} \mathrm{C}$ and $4^{\circ} \mathrm{C}$. However, from the current study, the storage moisture content was below $13 \%$ for the modified storage room, which makes it safe to store seeds for the purpose of quality preservation. The temperature inside the seed bags $\left(26.7 \pm 2.70^{\circ} \mathrm{C}\right)$ was slightly higher than the air temperature at the centre $\left(24.4 \pm 3.89^{\circ} \mathrm{C}\right)$ near the seed bags as a result of the heat of respiration of seeds during storage which raised the temperature between the seeds [34].

There was a significant difference $(\mathrm{P} \leq 0.05)$ between the $\mathrm{RH}$ in the control and modified storage facilities. Seed bags stored in the modified storage room had a lower RH (44.4 $\pm 6.11 \%)$ than in the control storage room $(66.1 \pm 7.34 \%)$ (Figure 4$)$, since the modified storage facility had hot air coming in during the day. In the study carried out by Nagel and Börner [15], maize seeds remained viable for 19 years at a $20.3 \pm 2.3^{\circ} \mathrm{C}$ and $50.3 \pm$ $6.3 \% \mathrm{RH}$. The RH obtained from the control storage exceeded that of Nagel and Börner [15], while that in the modified storage room was just below. Therefore, there is a great chance of improving the longevity of seeds when they are stored in the modified storage room, when one considers such results.

\section{Air relative humidity and temperature at the centre of the storage facilities at night}

There was a significant difference $(\mathrm{P} \leq 0.05)$ between the temperatures in the modified and control storage rooms at night. The temperature in the modified storage room decreased below the temperature in the control storage room. Since the solar collector did not operate at night, the expectation was approximate equal temperatures in both storage rooms. The average in the seed bags temperature in the control and modified storage room were $22.4 \pm 5.36^{\circ} \mathrm{C}$ and $20.9 \pm 4.11^{\circ} \mathrm{C}$, respectively, (Figure 6). It is noted that the difference in temperatures is $1.5^{\circ} \mathrm{C}$ at night are marginally compared to during the day of $5.3^{\circ} \mathrm{C}$. 

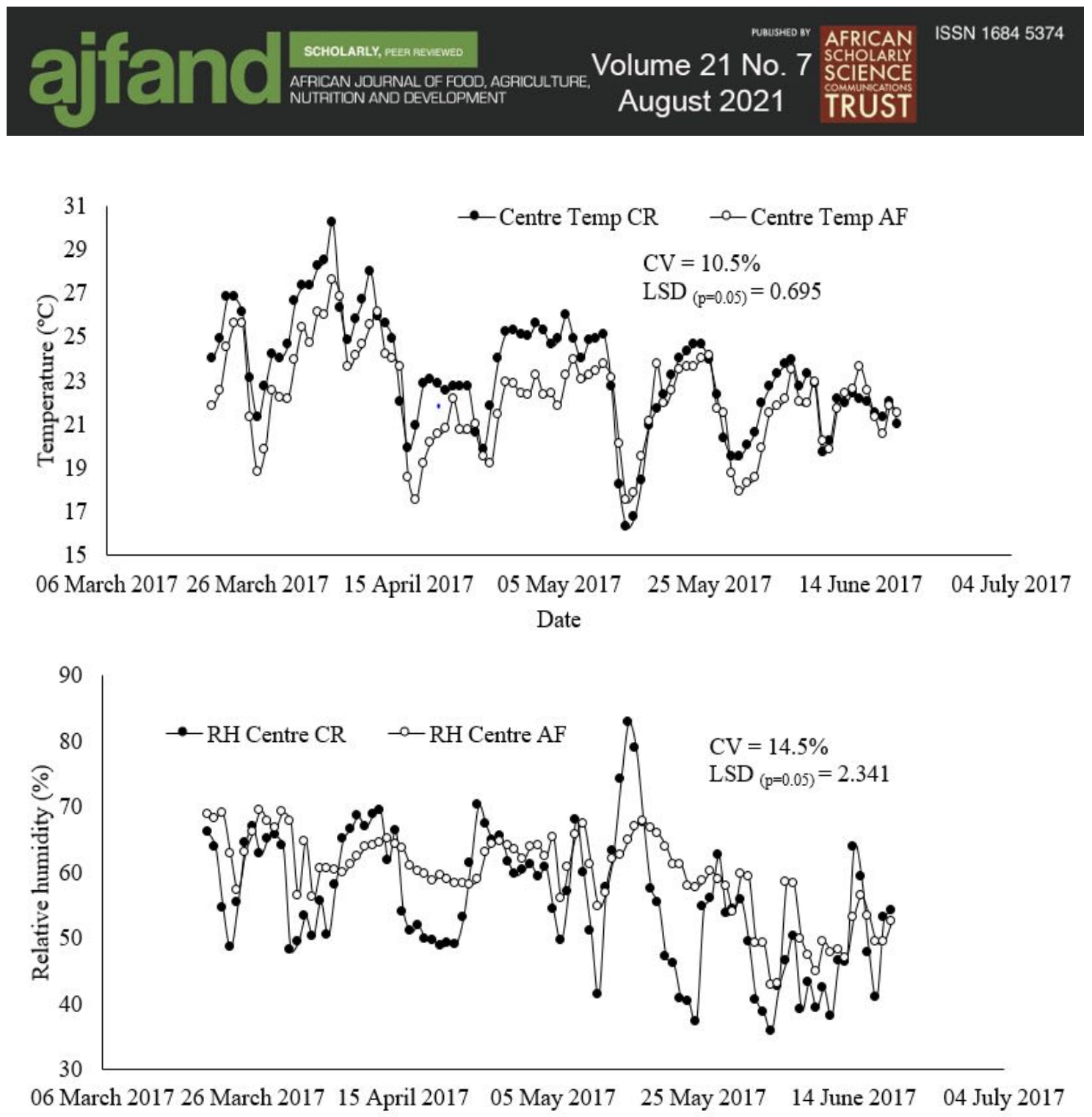

Figure 6: Centre temperatures and relative humidity for control room (CR) and modified room (AF) during at night

The average temperature during the day in the modified storage room was higher $(24.4$ $\left.\pm 3.89^{\circ} \mathrm{C}\right)$ than the average temperature at night $\left(22.2 \pm 6.12^{\circ} \mathrm{C}\right)$. However, the results obtained from the control storage room show that the average temperature during the day was slightly lower $\left(19.5 \pm 2.99^{\circ} \mathrm{C}\right)$ than the average temperature at night $(21.4 \pm$ $\left.4.25^{\circ} \mathrm{C}\right)$.

Seeds were tested for vigour, germination and moisture when stored at $4{ }^{\circ} \mathrm{C}, 25^{\circ} \mathrm{C}$ and $40^{\circ} \mathrm{C}$ under a constant $\mathrm{RH}$ of $45 \%$ for the duration of one year by Strelec [35]. After 90 days, the seed stored at $40^{\circ} \mathrm{C}$ had greater loss, compared to $25^{\circ} \mathrm{C}$ and $4{ }^{\circ} \mathrm{C}$. According to Jelle [31], seeds can be kept under a varied range of temperatures, provided they are dried to a safe moisture level and that the RH does not increase their moisture during storage. Therefore, the temperature is not a problem when the $\mathrm{RH}$ and moisture are kept low [32]. A low RH during storage reduces the rate of seed deterioration [36]. During the night in the modified storage room, the temperatures were low; however, the RH was high, implying that there was a risk of the seed moisture increasing. 


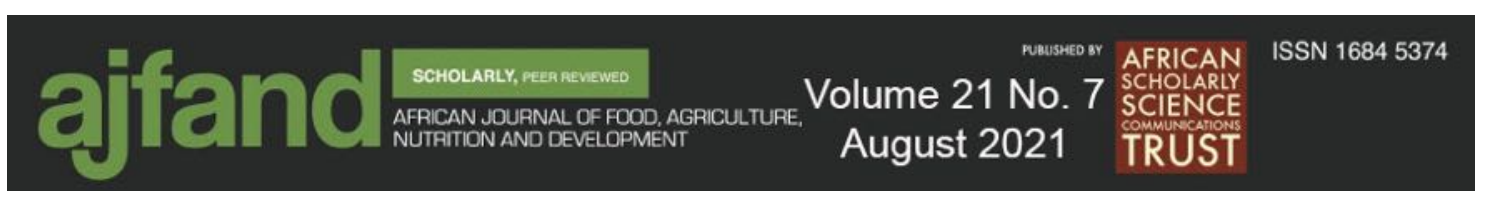

There was a significant difference $((\mathrm{P} \leq 0.05)$ between $\mathrm{RH}$ in the control and modified storage rooms. The RH in the modified storage room at night was higher than during the day. At night, the $\mathrm{RH}$ of the ambient air is high and as a result, the $\mathrm{RH}$ of the air in the storage room increases. The average $\mathrm{RH}$ in the control and modified storage room was $58.5 \pm 7.32 \%$ and $63.7 \pm 6.28 \%$, respectively (Figure 5). Seeds stay longer when dried to $11 \%$ or less at a temperature of $25 \pm 3^{\circ} \mathrm{C}$, and a $\mathrm{RH}$ of $70-75 \%$ according to Hettiarachchi [37]. The results of both storage rooms are in agreement with the results of Hettiarachchi [37], except for the moisture content, which is greater than $11 \%$. The $\mathrm{RH}$ in the modified storage room rose from $40.1 \pm 3.21 \%$ during the day to $63.7 \pm$ $6.28 \%$ at night.

In the control storage room, $\mathrm{RH}$ decreased slightly from $60.6 \pm 5.87 \%$ during the day to $58.5 \pm 7.32 \%$ at night, thus maintaining almost the same conditions throughout the day and night. To achieve the same conditions in the modified storage room throughout the day and night the structure should be closed when the sun sets as this will ensure that air $\mathrm{RH}$ does not rise at night.

\section{Air relative humidity and temperature at the centre of the seed bags at night} The temperature inside the seed bags in the modified storage room dropped below the one inside the seed bags in the control during the night (Figure 7). The average temperature in the modified storage room was $22.4 \pm 5.36^{\circ} \mathrm{C}$ while that in the seed bags in the control storage room was $20.9 \pm 4.11^{\circ} \mathrm{C}$. There was a significant difference $(\mathrm{P} \leq 0.05)$ between the temperature in the seed bags stored in the modified and the control storage rooms. The temperature inside the seed bags in the control room during the day was slightly lower $\left(21.4 \pm 4.25^{\circ} \mathrm{C}\right)$ than at night $\left(22.4 \pm 5.36^{\circ} \mathrm{C}\right)$. This may be due to the heat released at night, which is gained by the storage room during the sunshine hours of the day. This raised the temperature inside the structure as alluded to by Marshall et al. [38]. 

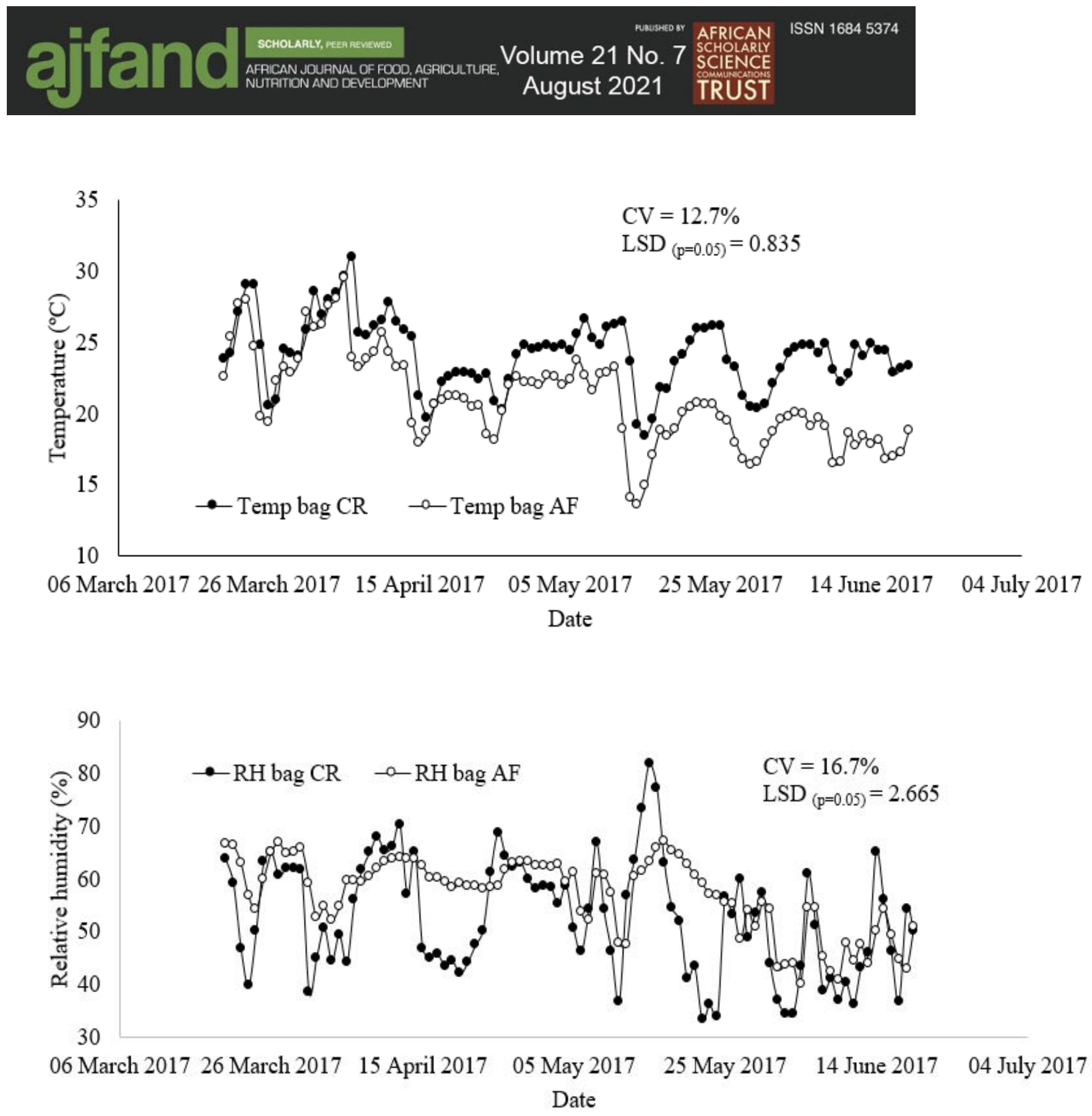

Figure 7: Seed bag temperature and relative humidity for control room (CR) and modified room (AF) at night

The opposite occurred in the modified storage room, as the temperature inside the seed bags during the day was higher $\left(26.7 \pm 2.70^{\circ} \mathrm{C}\right)$ than at night $\left(20.9 \pm 4.11^{\circ} \mathrm{C}\right)$. A decrease in temperature in the modified storage room at night was due to both the operation of the storage room at night and that temperatures are low at this time of the day. The difference between the RH in the control and modified storage rooms was significant $(\mathrm{P} \leq 0.05)$. The $\mathrm{RH}$ inside the seed bags stored in the modified storage room $(57 \pm 6.07 \%)$ was higher than the RH in the control storage $(52.7 \pm 8.65 \%)$. This could be attributable to the high RH air entering the storage at night (Figure 7). The outdoor $\mathrm{RH}$ at night is high, and, as a result, the indoor RH increases since the storage introduces fresh air from outdoors during its operation. Seed bags in the control room had a higher RH $(66.1 \pm 7.34 \%)$ during the day than at night $(57 \pm 6.07 \%)$. However, the 


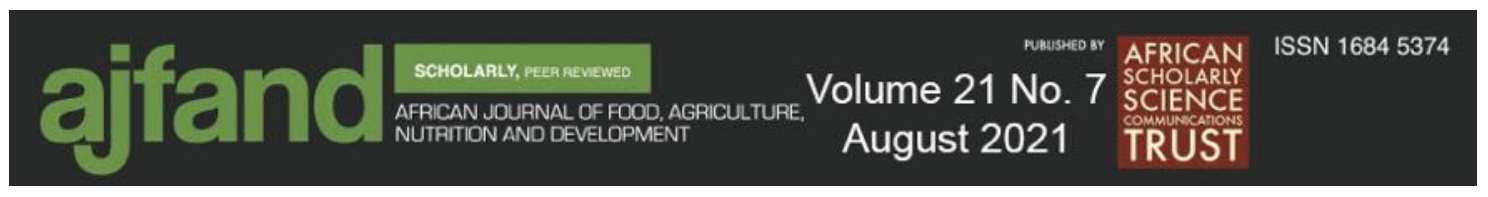

$\mathrm{RH}$ inside the seed bag in the modified storage room exhibited different behaviour, as it was higher at night $(66.1 \pm 7.34 \%)$ than during the day $(44.4 \pm 6.11 \%)$. The RH in the modified storage room was high, since it draws in high ambient air, with high RH at night and there is no solar energy to assist in reducing it.

\section{Seed moisture content}

There were significant differences $(\mathrm{P} \leq 0.05)$ between the moisture content of seeds stored in the modified and control storage rooms.

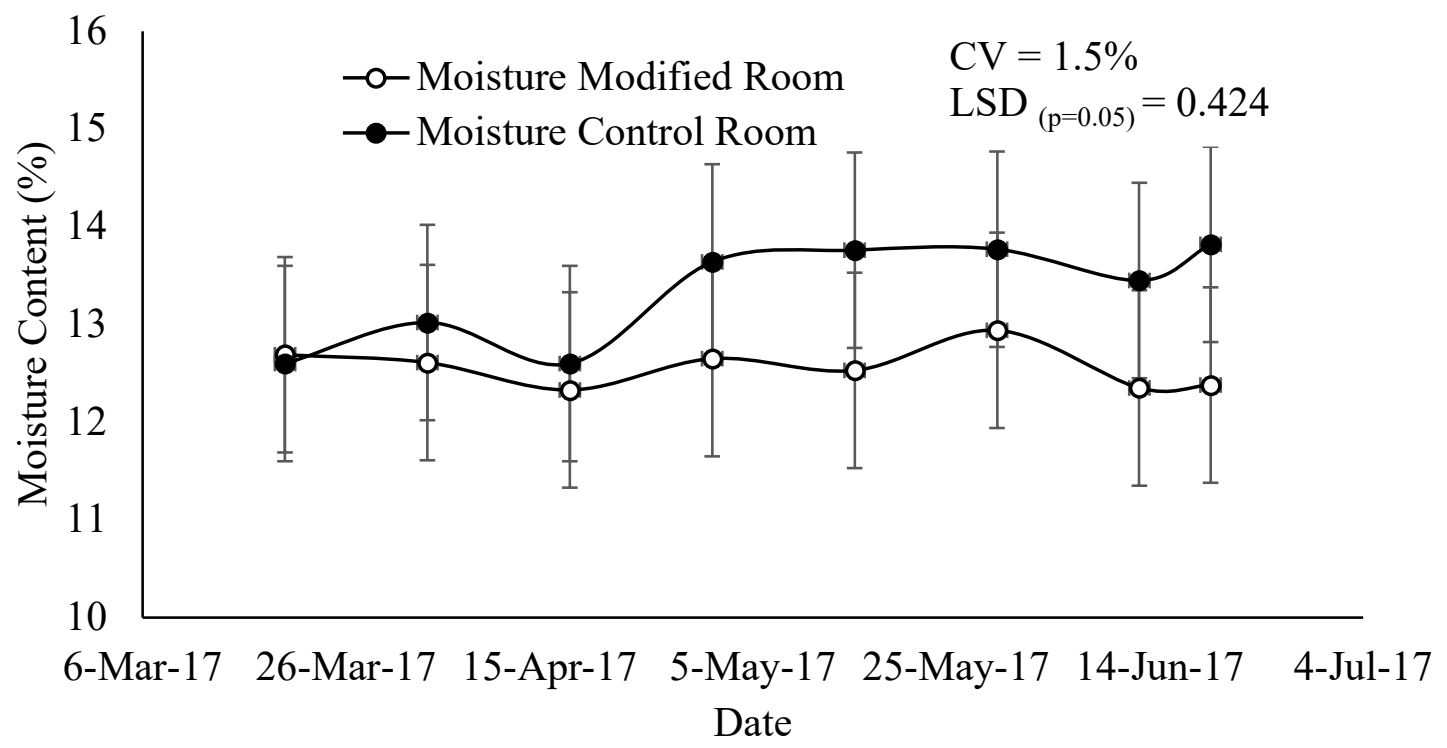

Figure 8: Seed moisture content for control room (CR) and modified room (AF)

The seed moisture content in the modified storage decreased from $12.6 \%$ to $12.4 \%$ over the period of three months of storage. On the other hand, the moisture content of the seeds stored in the control storage room increased from $12.6 \%$ to $13.8 \%$ during the same period (Figure 8 and Table1). The moisture content in the modified storage room decreased due to the lower RH air supplied by the storage in the presence of solar energy. Increasing RH increases the moisture content during seed storage and high moisture content decreases the seed longevity as reported by Kehinde [35] and Dai et al. [39]. In an environment where the moisture content is $12-13 \%$, seeds could be viable for 8-12 months [40]. The moisture content (12-13\%) achieved by the storage room over the period of storage is good for enhancing seed shelf life according to Brownfields and Seeds [28] and Matthews and Rushings [41]. Other authors like Govender et al. [7], Weinberg et al [8] and Welche and Delouche [42] regard any moisture content of less than $14 \%$ wet basis during storage as safe. Therefore, the seed moisture content achieved in the modified storage room will improve the storability of seeds.

\section{Seed germination and vigour}

There were significant differences $(\mathrm{P} \leq 0.05)$ in the germination rates between seeds stored in the control storage room and the modified storage room. The germination rate of seeds stored in the control storage room decreased faster than of the seeds in the 


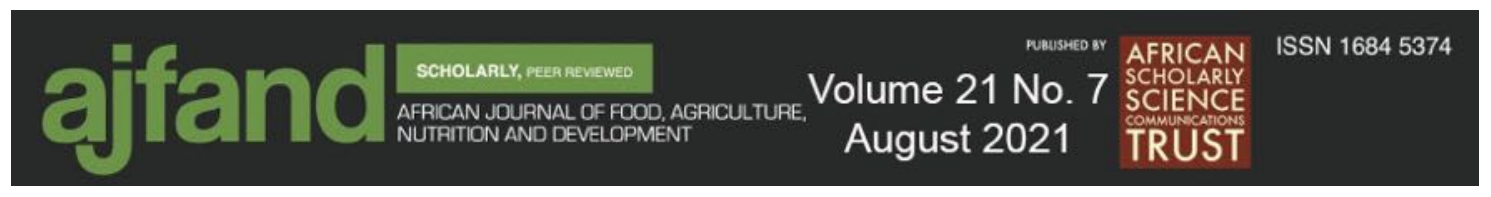

modified storage room (see Figure 8). In the control storage, germination decreased from $99 \%$ to $94 \%$ while in the modified storage room decreased from $99 \%$ to $97 \%$ over the period of three months. The germination percentage is influenced by the storage conditions. High temperature and RH accelerate the deterioration of stored seeds [4]. For the maize stored for a period of one year in a general storage room, with no ventilation and with temperatures of $35^{\circ} \mathrm{C}-37^{\circ} \mathrm{C}$, germination was reduced drastically from $88.7 \%$ to $0.0 \%$ [7]. The germination and vigour of seeds stored at a temperature of $40 \pm 2{ }^{\circ} \mathrm{C}$ and varying $\mathrm{RH}$ of $11 \%, 32 \%, 50 \%$, and $75 \%$ over a period of three months were studied by Suma et al. [43]. The results showed that an elevated RH (75\%) considerably decreased the quality of the seeds, as the germination rate reduced from $85 \%$ to $30 \%$ within the period of storage. The RH obtained from the current study is higher in the control room $(66.1 \pm 7.34 \%)$ than in the modified room $(44.4 \pm 6.11 \%)$, which might be the reason why the germination rate in the control room dropped faster than in the modified room. Overall, the modified storage room performed better than the control storage room.

The vigour results are expressed as germination percentages. There was a significant difference $(\mathrm{P} \leq 0.05)$ between the seed vigour obtained from both storages room. After accelerated ageing, the seed vigour of the modified storage room decreased from $94 \%$ to $93 \%$, while that of the control storage room decreased drastically from $95 \%$ to $88 \%$ over a period of three months (Figure 8 ). The difference between germination and vigour should be at most $15 \%$ [25]. 

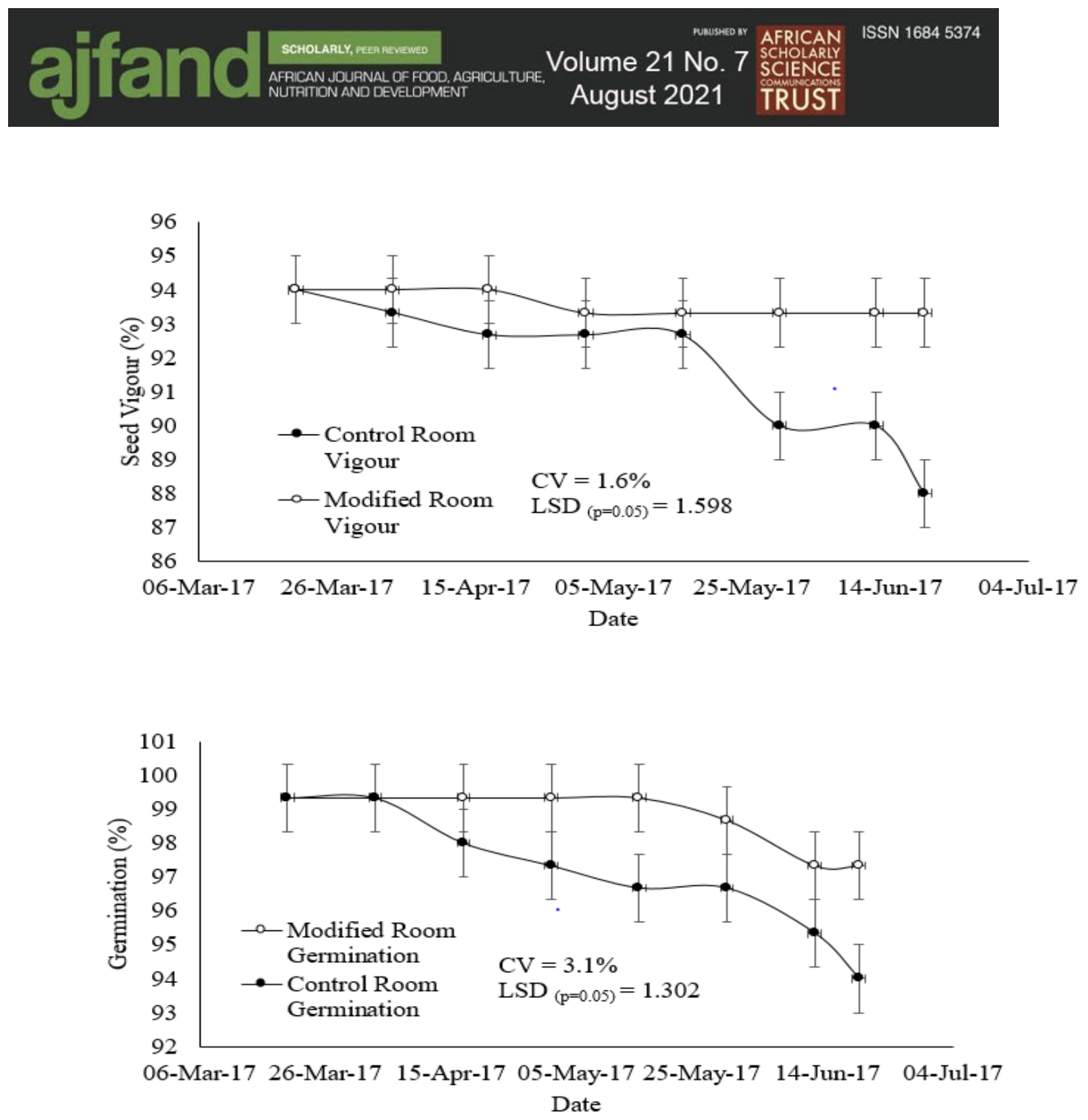

Figure 8: Seed germination percentage and seed vigour percentage for control room and modified room

This is in agreement with the results of seed vigour. The seed vigour percentage in this study was close to that of germination and this according to Seed Check [27] is an indication of good vigour. Both storage rooms were successful in preserving vigour over the storage period. However, the control storage lost vigour quicker than the modified storage room, which was due to the different conditions provided by different storage rooms.

\section{CONCLUSION}

A significantly lower RH (40.1\%) was achieved during the day, as was expected, due to the availability of solar energy, compared to that in the control storage room. However, at night a high RH was dominant, especially in the developed storage room (63.7\%). Therefore, to ensure that a low RH is achievable, a modified storage room should only be open during the day and closed at night. When it is open during the day, the hot air 


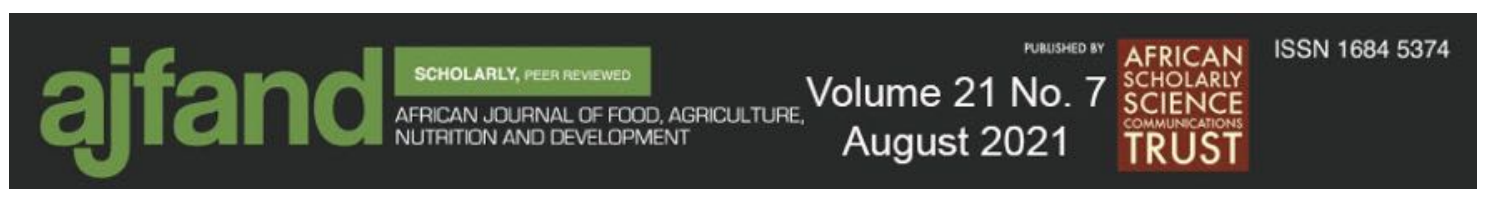

in the roof solar collector is utilised to reduce the RH in the storage environment, and when closed at night, the ambient air, with high RH is avoided.

An increase in the moisture content is dependent on the environmental conditions during storage. The moisture content decreased from $12.6 \%$ to $12.4 \%$ in the modified storage room, whereas it increased in the control storage room from $12.6 \%$ to $13.8 \%$. Therefore, the modified storage room is good, in terms of keeping the seed moisture content below $14 \%$ during storage.

The average germination percentages decreased from $99 \%$ to $96.8 \pm 1.49 \%$ and $98.5 \pm$ $0.85 \%$ for the control and modified storage rooms respectively after three months of storage indicating good storability. The germination percentage decreased faster in the control room than in the modified room. Seed vigour declined marginally in the modified storage room compared to the control storage room. Thus, the developed storage room performed better than the control storage room and was able to preserve the seed quality during storage.

The modified storage room needs to be evaluated during the summer months. Moreover, it should be tested over a longer period, for example, a year in order to observe how the seed quality parameters change over time. 


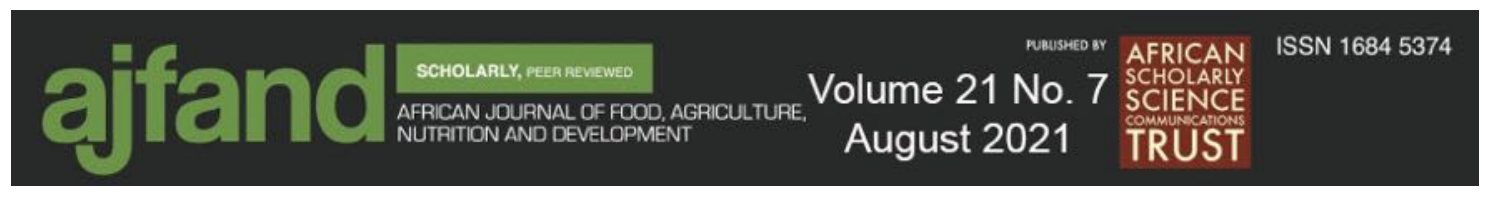

Table 1: Results of temperature and relative humidity in the centre and inside the seed bags, moisture content, germination and seed vigour in the control and modified room

\begin{tabular}{|l|l|l|l|l|l|l|l|}
\hline & $\begin{array}{l}\text { Centre } \\
\text { Temp }\end{array}$ & $\begin{array}{l}\text { Centre } \\
\text { RH }\end{array}$ & $\begin{array}{l}\text { Bag } \\
\text { Temp }\end{array}$ & Bag RH & Moisture & Germination & Vigour \\
\hline Cont.room Av.D & $19.5 \pm 2.99$ & $60.6 \pm 5.87$ & $21.4 \pm 2.67$ & $66.1 \pm 7.34$ & $13.3 \pm 0.52$ & $96.8 \pm 1.49$ & $91.7 \pm 2.08$ \\
\hline Mod.room Av.D & $24.4 \pm 3.89$ & $40.1 \pm 3.21$ & $26.7 \pm 2.70$ & $44.4 \pm 6.11$ & $12.6 \pm 0.21$ & $98.5 \pm 0.85$ & $93.6 \pm 0.35$ \\
\hline Cont.room.Av.N & $21.4 \pm 4.25$ & $58.5 \pm 7.32$ & $22.4 \pm 5.36$ & $52.7 \pm 8.65$ & $13.3 \pm 0.52$ & $96.8 \pm 1.49$ & $91.7 \pm 2.08$ \\
\hline Mod.room.Av.N & $22.2 \pm 6.12$ & $63.7 \pm 6.28$ & $20.9 \pm 4.11$ & $57 \pm 6.07$ & $12.6 \pm 0.21$ & $98.5 \pm 0.85$ & $93.6 \pm 0.35$ \\
\hline CV (\%).D & 15.8 & 17.6 & 11.2 & 16.2 & 1.5 & 3.1 & 1.6 \\
\hline CV (\%).N & 10.5 & 14.5 & 12.7 & 16.7 & 1.5 & 3.1 & 1.6 \\
\hline p value.D & $<0.001$ & $<0.001$ & $<0,001$ & $<0.001$ & 0.002 & 0.012 & 0.022 \\
\hline p value. N & 0.001 & $<0.001$ & $<0.001$ & 0.002 & 0.002 & 0.012 & 0.022 \\
\hline LSD(p=0,05).D & 1.008 & 2.585 & 0.784 & 3.090 & 0.424 & 1.302 & 1.598 \\
\hline LSD (p=0.05).N & 0.695 & 2.341 & 0.835 & 2.665 & 0.424 & 1.302 & 1.598 \\
\hline
\end{tabular}

Where $\mathrm{CV}=$ coefficient of variation; LSD $=$ least significant difference at $p=0.05$;

Cont.room $\mathrm{Av}=$ average value in the control room; Mod.room $\mathrm{Av}=$ average value in the modified storage $\mathrm{D}=$ during the day; $\mathrm{N}=$ at night 


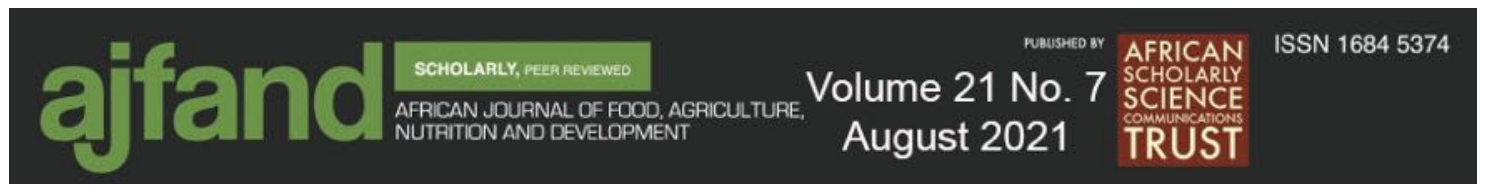

\section{REFERENCES}

1. Gonzales HB, Armstrong PR and RG Maghirang Simultaneous monitoring of stored grain with relative humidity, and carbon dioxide sensors. Applied Engineering in Agriculture 2009; 25(4): 595-604.

2. Lawrence $\mathbf{J}$ and $\mathbf{D E}$ Maier Aeration strategy simulation for wheat storage in the sub-tropical region of north India. Transactions of the ASABE 2010; 54(4):13951405.

3. Suleiman RA, Rosentrater KA and CJ Bern Effects of deterioration parameters on storage of maize. Iowa State University, Ames, USA. 2013: Report No. 9.

4. Delouche JC, Matthes RK, Dougherty GM and AH Boyd Storage of seed in sub-tropical and tropical regions. Seed Science and Technology 2016; 1(2016): 671-700.

5. Rao NK, Dulloo ME and JMM Engels A review of factors that influence the production of quality seed for long-term conservation in genebanks. Genetic Resources and Crop Evolution 2017; 64(5): 1061-1074.

6. Sharon M, Abirami $\mathbf{C}$ and $\mathbf{K}$ Alagusundaram Grain storage management in India. Journal of Post-Harvest Technology 2014; 2(1): 12-24.

7. Govender V, Aveling TAS and Q Kritzinger The effect of traditional storage methods on germination and vigour of maize (Zea mays L.) from northern KwaZulu-Natal and southern Mozambique. South African Journal of Botany 2008; 74(2): 190-196.

8. Weinberg ZG, Yan Y, Chen Y, Finkelman S, Ashbell G and Y Navarroa The effect of moisture level on high-moisture maize (Zea mays L.) under hermetic storage conditions - in vitro studies. Journal of Stored Products Research 2008; 44(2008): 136-144.

9. Coasta DM, Machado LC, Bittencourt F and LC Pereira Quality of maize for commercially available animal nutirion and methods for determining moisture. Agrogeoambiental Magazine 2013; 5(2): 25-34.

10. Coradi PC, Camilo LJ, Cunha FF, Pereira TLL and CZ Alves Alternatives of storage of corn grains for the conditions of the Brazilian Cerrado. Bioscience Journal 2016; 32(1): 29-40.

11. Chiu K, Chen $\mathbf{C}$ and J Sung Effect of priming temperature on storability of primed sweet corn seed. Crop Science 2002; 42(6): 1996-2003.

12. Jian F and DS Jayas The ecosystem approach to grain storage. Agricultural Research 2012; 1(2):148-156. 




13. Moreno-Martinez E, Vazquez-Badillo M, Rivera A, Navarrete $\mathbf{R}$ and $\mathbf{F}$ Esquivel-Villagrana Effect of seed shape and size on germination of corn (Zea mays L.) stored under adverse conditions. Seed Science and Technology 1998; 26(2): 439-448.

14. Joao Abba $\mathbf{E}$ and A Lovato Effect of seed storage temperature and relative humidity on maize (Zea mays L.) seed viability and vigour. Seed Science and Technology 1999; 27(1): 101-114.

15. Nagel M and A Börner The longevity of crop seeds stored under ambient conditions. Seed Science Research 2010; 20(1): 1-12.

16. Šimić B, Sudarić A, Liović I, Kalinović I, Rozman V and J Ćosić Influence of storage conditions on seed quality of maize, soybean, and sunflower. The Agricultural Institute Osijek, Osijek, Croatia. 2006; Report No. PS1-7-6121.

17. White SD, Murphy PT, Bern CJ and JH van Leeuwen Controlling deterioration of high-moisture maize with ozone treatment. Journal of Stored Products Research 2010; 46(1): 7-12.

18. Somavat P, Huang H, Kumar S, Garg MK, Danao M-GC, Singh V, Paulsen MR and KD Rausch Comparison of hermetic storage of wheat with traditional storage methods in India. Applied Engineering in Agriculture 2017; 33(1): 121130.

19. Tefera $\mathbf{T}$ Post-harvest losses in African maize in the face of increasing food shortage. Food Security 2012; 4(2): 267-277.

20. Soponronnarit S Energy model of grain drying system. ASEAN Journal on Science and Technology for Development 2017; 5(2): 43-68.

21. Everson CS, Mengistu MG and MB Gush A field Assessment of the agronomic performance and water use of Jatropha curcas in South Africa. Biomass and Energy 2013; 59:59-69.

22. Windfinder. Wind Weather Statistics. [Internet]. Windfinder, Amsterdam, the Netherlands. http://www.windfinder.com/windstatistics/pietermaritzburg [Accessed: 15 May 2020] 2016.

23. Horwitz W, Chichilo P and H Reynolds Official Methods of Analysis of the Association of Official Analytical Chemists. Association of Official Analytical Chemists, Washington, DC, USA. 1970.

24. Janmohammadi M, Dezfuli PM and F Sharifzadeh Seed invigoration techniques to improve germination and early growth of inbred line of maize under salinity and drought stress. Gen. Appl. Plant Physiol 2008; 34(3-4): 215-226. 


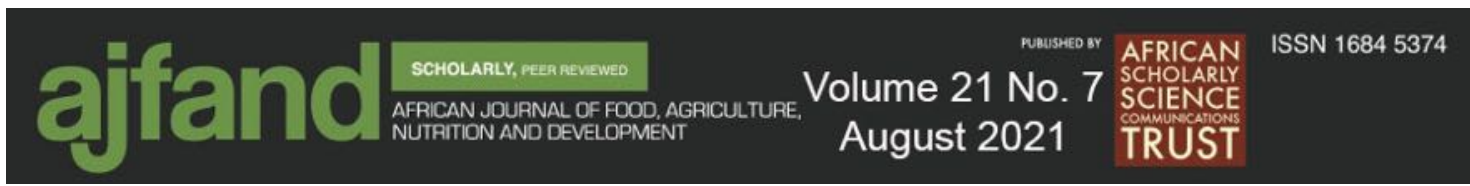

25. iGrow Corn. Corn Seed Testing. [Internet]. iGrow Corn, Brookings, USA. 2016; Available from: https://igrow.org/up/resources/03-5000-2016-06.pdf. [Accessed: 28 June 2017].

26 Soltani E, Ghaderi-Far F, Baskin C C and JM Baskin Problems with using mean germination time to calculate rate of seed germination. Australian Journal of Botany 2-15; 63: 631-635. https://doi.org/10.1071/BT15133

27. Seed Check. Accelerated Ageing Vigour Test. [Internet]. Seed Check, Leduc, Canada. 2017. Available from: http://www.seedcheck.net/seed-checktests/vigour/accelerated-ageing-vigour-test/ [Accessed: 29 June 2017] .

28. Brownfield P and S Seeds The Effects of Storage Conditions on Seed Shelf Life. [Internet]. Rogers, Rogers, USA. 2006. Available from:

https://www.seedquest.com/id/r/rogers/pdf/seedstorage.pdf [Accessed: 10 July 2017].

29. Lee S-S, Yun S-H, Yan S-K and S-B Hong Changes in seed vigour of sweet and super sweet corn hybrids as affected by storage conditions. Korean Journal of Crop Science 2006; 51(5): 432-439.

30 Matthes RK, Dougherty GM, Delouche JC and AH Boyd Drying, processing and storage of corn seed in tropical and sub-tropical regions. Seed Storage 2016; 1(2016): $1-15$.

31. Jelle H The Storage of Tropical Agricultural Products. Agromisa Foundation, Wageningen, the Netherlands. 2003: Report No. 835.

32 Mira S, Estrelles E and ME González-Benito Effect of water content and temperature on seed longevity of seven Brassicaceae species after 5 years of storage. Plant Biology 2015; 17(1): 153-162.

33. Wang N Impact of low-temperature storage on quality of high-moisture corn grain. University of Illinois, Normal, USA. 2015: Report No. 5.

34. Martin DT, Baributsa D, Huesing JE, Williams SB and LL Murdock PICS bags protect wheat grain, Triticum aestivum (L.), against rice weevil, Sitophilus oryzae (L.)(Coleoptera: Curculionidae). Journal of Stored Products Research 2015; 63(2015): 22-30.

35. Strelec I, Popovic R, Ivanisic I, Jurkovic V, Jurkovic Z, Ugarcic-Hardi Z and M Sabo Influence of temperature and relative humidity on grain moisture, germination and vigour of three wheat cultivars during one year storage. Poljoprivreds 2010; 6(2010): 20-24.

36. Kehinde OO Longevity of Maize Seeds under Controlled and Open storage System. Babcock University, Ilishan Remo, Nigeria. 2013. 


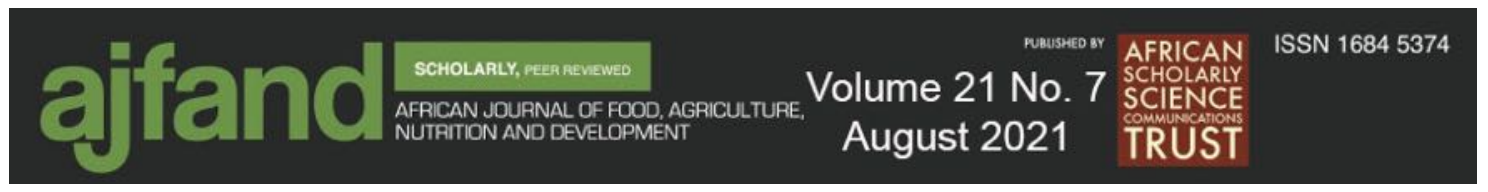

37. Hettiarachchi GHCM, Goonaratne $\mathbf{J}$ and WK Hirimburegama Effect of initial moisture content and relative humidity on the accumulation of afalatoxin in maize grains (Zea Mays) during storage. Journal of the National Science Foundation of Sri Lanka 2010; 29(2010): 29-34.

38. Marshall E, Steinberger JK, Dupont $\mathbf{V}$ and TJ Foxon Combining energy efficiency measure approaches and occupancy patterns in building modelling in the UK residential context. Energy and Buildings 2016; 111(2016): 98-108.

39. Dai J-W, Rao J-Q, Wang D, Xie L, Xiao H-W, Liu Y-H and Z-J Gao Processbased drying temperature and humidity integration control enhances drying kinetics of apricot halves. Drying Technology 2015; 33(3): 365-376.

40. Osueke OC Design modelling of a fluidized bed for grain drying. Journal of Engineering Research and Development 2013; 7(9): 10-15.

41. Matthes K and KW Rushing Seed drying and conditioning. Seed Technology 2016; 4(7): 256-264.

42. Welch GB and JC Delouche Seed processing and storage facilities for tropical areas. Seed Science 2016; 3(5): 1-12.

43. Suma A, Sreenivasan K, Singh AK and J Radhamani Role of relative humidity in processing and storage of seeds and assessment of variability in storage behaviour in Brassica spp. and Eruca sativa. The Scientific World Journal 2013; 1(2013): 1-9. 